\title{
PENGARUH TINGKAT PROFITABILITAS , REPUTASI AUDITOR DANUKURAN PERUSAHAAN TERHADAP AUDIT DELAY PADA PERUSAHAAN LQ 45 TAHUN 2010 - 2016
}

\author{
Turini \\ Universitas Catur Insan Cendekia \\ Jl. Kesambi 202, Kota Cirebon, Jawa Barat \\ e-mail : riniherdi@yahoo.co.id
}

\begin{abstract}
ABSTRAK
Penelitian ini bertujuan untuk mengetahui pengaruh tingkat profitabilitas yang diukur dengan ROA terhadap audit delay, pengaruh reputasi auditor yang diukur dengan variabel dummy terhadap audit delay, pengaruh ukuran perusahaan yang diukur dengan size terhadap audit delay . Metode penelitian yang digunakan dalam penelitian ini yaitu deskriptif, dengan menggunakan data sekunder, Populasi dalam penelitian ini adalah seluruh perusahaan LQ 45 yang terdaftar di bursa efek indonesia tahun 2010 sampai dengan tahun 2016. Pengambilan sampel dilakukan dengan menggunakan metode purposive sampling sampai diperoleh 24 sampel. Berdasarkan hasil analisis regresi berganda, maka dapat disimpulkan tingakt profitabilitas yang diukur dengan ROA berpengaruh terhadap audit delay pada perusahaan LQ 45 tahun 2010-2016, reputasi auditor yang diukur dengan variabel dummy tidak berpengaruh terhadap audit delay pada perusahaan LQ 4545 tahun 2010-2016, ukura perusahaan yang diukur dengan Size berpengaruh terhadap audit delay pada perusahaan LQ 45 tahun 2010-2016,
\end{abstract}

Kata kunci : Audit delay, Profitabilitas, Reputasi Auditor dan Ukuran Perusahaan

\section{ABSTRACT}

This study aims to determine the effect of the level of profitability as measured by ROA on audit delay, the effect of auditor reputation as measured by dummy variables on audit delay, the effect of company size as measured by size on audit delay. The research method used in this research is descriptive, using secondary data. The population in this study were all LQ 45 companies listed on the Indonesian stock exchange from 2010 to 2016. Sampling was carried out using purposive sampling method until 24 samples were obtained. Based on the results of multiple regression analysis, it can be concluded that the level of profitability as measured by ROA has an effect on audit delay in LQ 45 companies in 2010-2016, auditor reputation as measured by dummy variables has no effect on audit delay in LQ 45 companies in 2010-2016, company size as measured by Size has an effect on audit delay in LQ 45 companies in 2010-2016,

Keywords: Audit delay, Profitability, Auditor Reputation and Company Size

\section{PENDAHULUAN}

\subsection{Latar Belakang}

Bursa Efek Indonesia kini berkembang pesat. Perkembangan tersebut ditandai dengan berkembangnya perusahaan-perusahaan yang go public, maka hal ini akan berdampak pada peningkatan permintaan akan audit laporan keuangan yang efektif dan efisien. Laporan keuangan ini digunakan untuk kepentingan manajemen perusahaan dan juga digunakan oleh pemilik untuk menilai pengelolaan dana yang dilakukan oleh manajemen perusahaan, selain itu juga para investor, kreditor, pemerintah, masyarakat dan

Pengaruh Tingkat Profitabilitas, Reputasi Auditor Danukuran Perusahaan Terhadap Audit Delay Pada Perusahaan LQ 45 Tahun 2010 - 2016-(Turini) 
pihak-pihak lain juga membutuhkan laporan keuangan ini sebagai dasar pengambilan suatu keputusan Ketepatan waktu penyusunan atau pelaporan suatu laporan keuangan perusahaan dapat berpengaruh pada nilai laporan keuangan tersebut. Karena laporan keuangan yang sudah diaudit yang di dalamnya memuat informasi laba yang dihasilkan sebagai salah satu dasar pengambilan keputusan untuk membeli atau menjual kepemilikan yang dimiliki oleh investor. Artinya informasi laba dari laporan keuangan yang dipublikasikan akan menyebabkan kenaikan atau penurunan harga saham.

Sebelumnya ketepatan waktu penyampaian laporan keuangan telah diatur dalam pasar modal yaitu dalam Undang-undang Nomor 8 Tahun 1995 tentang "Peraturan Pasar Modal" menyatakan bahwa semua perusahaan yang terdaftar dalam pasar modal wajib menyampaikan laporan keuangan secara berkala kepada Bapepam dan mengumumkan kepada masyarakat. Apabila perusahaan-perusahaan tersebut terlambat menyampaikan laporan sesuai dengan dengan ketentuan yang telah ditetapkan oleh Bapepam, maka dikenakan sanksi administrasi sesuai dengan ketentuan yang telah ditetapkan dalam undang-undang. Peraturan mengenai penyampaian laporan keuangan ini telah diperbaharui oleh OJK pada tahun 1996, lampiran keputusan Ketua Bapepam Nomor: Kep-80/PM/1996 dan mulai berlaku pada tanggal 17 Januari 1996. Dalam pertauran baru ini disebutkan bahwa perusahaan wajib menyampaikan laporan keuangan tahunan yang telah diaudit selambat-lambatnya 120 hari terhitung sejak tanggal tutup buku perusahaan. Ketepatan waktu penyusunan atau pelaporan suatu laporan keuangan perusahaan dapat berpengaruh pada nilai laporan keuangan tersebut. Karena laporan keuangan yang sudah diaudit yang di dalamnya memuat informasi laba yang dihasilkan sebagai salah satu dasar pengambilan keputusan untuk membeli atau menjual kepemilikan yang dimiliki oleh investor. Artinya informasi laba dari laporan keuangan yang dipublikasikan akan menyebabkan kenaikan atau penurunan harga saham.

GAAS (Generally Accepted Auditing Standars) khususnya pada bagian standar umum ketiga menyatakan bahwa audit harus dilaksanakan dengan penuh kecermatan dan ketelitian. Seiring dengan hal tersebut, standar pekerjaan lapangan juga harus dilaksankan dengan perencanaan yang matang dan mengumpulkan alat-alat bukti yang memadai. Adakalanya, dalam melaksanakan standar-standar tersebut ditemukan adanya penyimpangan. Penyimpangan inilah yang kadang menyebabkan lamanya suatu proses pengauditan dilakukan karena adanya unsur verifikasi yang digunakan untuk mengusut indikasi penyimpangan yang terjadi. Proses ini memungkinkan publikasi laporan keuangan yang diharapkan secepat mungkin menjadi terlambat.Perusahaan besar lebih konsisten untuk tepatwaktu dibandingkan perusahaan kecil dalammenginformasikan laporan keuangannya.Pengaruh ini ditunjukkan dengansemakin besar nilai aktiva perusahaan makasemakin pendek audit delay dan sebaliknya.Perusahaan besar diduga akan menyelesaikanproses auditnya lebih cepat dibandingkanperusahaan kecil. Hal ini disebabkan olehbeberapa faktor yaitu manajemen perusahaanyang berskala besar cenderung diberikaninsentif untuk mengurangi audit delaydikarenakan perusahaan-perusahaan tersebutdimonitor secara ketat oleh investor,pengawas permodalan dari pemerintah. Pihak-pihak ini sangat berkepentinganterhadap informasi yang termuat dalam laporan keuangan.

Tingkat profitabilitas yang tingggi mengindikasikan bahwa perusahaan tersebut mengalami keuntungan, dengan hal tersebut berarti kemungkinan akan meminta auditornya agar menjadwalkan waktu audit lebih cepat. Sebaliknya perusahaan yang mendapatkan profitabilitas rendah atau mendapatkan kerugian memacu kemunduran publikasi laporan keuangan. Sehingga perusahaan dengan tingkat profitabilitas yang tinggi mempunyai audit delay yang lebih pendek karena itu merupakan berita baik yang harus segera disampaikan kepada para investor dan pihak yang berkepentingan lainnya (Ibid: 49). Faktor lain yang mempengaruhi audit delay adalah reputasi auditor. Kualitas audit berpengaruh terhadap kredibilitas laporan keuangan perusahaan go pubic. Dalam menyampaikan suatu laporan atau informasi akan kinerja perusahaan kepada publik yang akurat dan terpercaya, perusahaan diminta untuk menggunakan jasa KAP. Dan untuk meningkatkan kredibilitas dari laporan itu, perusahaan menggunakan jasa KAP yang mempunyai reputasi atau nama baik. Hal ini biasanya ditunjukkan dengan KAP yang berafiliasi dengan KAP besar yang berlaku universal yang dikenal dengan Big Four Worldwide Accounting Firm atau Big Four.

Besar kecilnya ukuran suatu perusahaan dapat didasarkan pada total nilai aktiva, total penjualan, kapitalisasi pasar, jumlah tenaga kerja dan sebagainya. Semakin besar aktiva suatu perusahaan maka akan semakin besar pula modal yang ditanam, semakin besar total penjualan suatu perusahaan maka akan semakin banyak juga perputaran uang dan semakin besar kapitalisasi pasar maka semakin besar pula perusahaan dikenal oleh masyarakat (Hilmi dan Ali, 2008)Berdasarkan uraian sebelumnya, maka perumusan masalahnya adalah adanya research gap dari penelitian-penelitian sebelumnya yang menunjukkan adanya keanekaragaman hasil penelitian tentang faktor-faktor yang mempengaruhi audit delay. Oleh karenanya dalam hal ini peneliti membahas tentang Pengaruh Tingkat Profitabilitas, Reputasi Auditor Dan Ukuran Perusahaan Terhadap Audit Delay Pada Perusaah LQ 45 Tahun 2010 - 2016. 


\subsection{Identifikasi Masalah}

Berdasarkan masalah yang dikemukakan, maka masalah yang menjadi perhatian peneliti dan menuntut pemecahan berkaitan dengan:

1. Bagaimana pengaruh Tingkat Profitabilitasterhadap Audit Delay pada Perusahan LQ 45 tahun 20102016 ?

2. Bagaimana pengaruh Reputasi Auditorterhadap Audit Delaypada Perusahan LQ 45 tahun 2010-2016?

3. Bagaimana pengaruh Ukuran Perusahaan terhadap Audit Delay pada Perusahan LQ 45 tahun 2010-2016 ?

4. Bagaimana pengaruh Tingkat Profitabilitas, Reputasi Auditor dan Ukuran Perusahaanterhadap Audit Delay pada Perusahan LQ 45 tahun 2010-2016?

\subsection{Batasan Masalah}

Penulis membatasi permasalahan dalam penulisan ini agar pembahasan tidak menyimpang dari tujuan, maka dilakukan pembatasan masalah yaitu penelitian ini adalah

1. Menganalisist tingkat profitabilitas tahun 2010 sampai dengan tahun 2016

2. menganalisis reputasi auditor tahun 2010 sampai dengan tahun 2016

3. menganalisis ukuran perusahaan tahun 2010 sampai dengan tahun 2016

4. Proses analisis laporan keuangannya menggunakan analisis rasio yang terdiri dari variabel dependen adalah audit delay, sedangkan pada variabel independen diantaranya adalah tingkat profitabilitas, reputasi auditor dan ukuran perusahaan .

\subsection{Tujuan Penelitian}

Adapun tujuan dibuatnya penelitian ini adalah sebagai berikut :

1. Untuk mengetahui pengaruh Tingkat Profitabilitasterhadap Audit Delay pada Perusahan LQ 45 tahun 2010-2016.

2. Untuk mengetahui pengaruh ReputasiAuditor terhadap Audit Delay Perusahan LQ 45 tahun 20102016.

3. Untuk mengetahui pengaruh Ukuran Perusahaanterhadap Audit Delay pada Perusahan LQ 45 tahun 2010-2016.

4. Untuk mengetahui pengaruh Tingkat Profitabilitas, Reputasi Auditor dan Ukuran Perusahaan terhadap Audit Delay pada Perusahan LQ 45 tahun 2010-2016.

\section{KAJIAN PUSTAKA}

\subsection{Audit Delay}

Variabel dependen dalam penelitian ini mengenai audit delay atau audit report lag. Definisi audit delay atau audit report lag menurut Tuanakotta, (2011), "Audit report lag adalah jarak waktu antara tanggal neraca dan tanggal laporan audit. Jarak waktu ini adalah gabungan antara waktu yang dibutuhkan klien untuk menyusun laporan keuangannya dan waktu untuk mengauditnya. Jika jarak waktu ini semakin panjang, ditengarai bahwa hal ini merupakan indikasi adanya masalah”.

Audit delay menurut Kartika (2009) di dalam jurnalnya sebagai berikut:“Audit delay merupakan lamanya / rentang waktu penyelesaian audit yang diukur dari tanggal tahun buku sampai dengan tanggal diterbitkannya laporan audit'. Definisi lain mengenai audit delaySubekti dan Widianti (2004) dalam jurnalnya Purnamasari (2012): "Lamanya atau rentang waktu penyelesaian audit yang diukur dari tanggal penutupan tahun buku sampai dengan tanggal diterbitkannya laporan audit. Perbedaan waktu yang sering dinamakan dengan audit delay adalah perbedaan antara tanggal laporan keuangan dengan tanggal opini audit dalam laporan keuangan yang mengindikasikan tentang lamanya waktu penyelesaian audit yang dilakukan oleh auditor'. Karena audit delay inilah yang mempengaruhi ketepatan waktu informasi yang dipublikasikan, sehingga akan berpengaruh terhadap ketidakpastian dalam pengambilan keputusan yang berdasarkan informasi yang dipublikasikan.

Lamanya waktu penyelesaian audit (audit delay) adalah waktu yang dibutuhkan dalam mengaudit laporan keuangan, yang dihitung dimulai berakhirnya tahun buku sampai dengan dikeluarkannya laporan auditor independen. Menurut Rachmawati (2008) mendefinisikan audit delay sebagai berikut : "Rentang waktu penyelesaian audit laporan keuangan tahunan, diukur berdasarkan lamanya hari yang dibutuhkan 
untuk memperoleh laporan auditor independen atas audit laporan keuangan tahunan perusahaan, sejak tanggal tahun tutup buku perusahaan sampai dengan tanggal yang tertera pada laporan auditor independen. 'Berdasarkan keputusan ketua Badan Pengawas Pasar Modal dan Lembaga Keuangan yang sekarang sudah berganti nama menjadi Otorisasi Jasa Keuangan (OJK) Nomor: KEP-36/BL/2011 tentang penyampaian laporan keuangan berkala emiten atau perusahaan publik. Peraturan BAPEPAM dan LK Nomor X.K.2 ini menyatakan bahwa laporan keuangan tahunan harus disertai dengan laporan akuntan dengan pendapat lazim dan disampaikan kepada BAPEPAM selambat-lambatnya pada akhir bulan ketiga (90 hari) setelah tanggal laporan keuangan tahunan.

Pada tahun 2012 berdasarkan keputusan ketua BAPEPAM nomor Kep-431/BL/2012 Tanggal 1 Agustus 2012 peraturan nomor X.K.6 tentang Penyampaian Laporan Tahunan Emiten atau Perusahaan Publik menyatakan bahwa Emiten atau Perusahaan Publik yang pernyataan pendaftarannya telah menjadi efektif wajib menyampaikan laporan tahunan kepada BAPEPAM paling lama 4 (empat) bulan setelah tahun buku berakhir.Dalam penelitian ini, audit delay dapat diketahui melalui selisih antara tanggal tahun tutup bukunya laporan keuangan sampai dengan tanggal yang tertera di laporan audit yang dikeluarkan oleh KAP.

\subsection{Tingkat Profitabilitas}

Harahap (2013: 304), mengemukakan rasio profitabilitas yaitu :

"Rasio yang menggambarkan kemampuan perusahaan mendapatkan laba melalui semua kemampuan, dan sumber yang ada seperti kegiatan penjualan, kas, modal, jumlah karyawan, jumlah cabang dan sebagainya." Sedangkan menurut Fahmi (2014:135), mengemukakan rasio profitabilitas yaitu "Rasio ini mengukur efektifitas manajemen secara keseluruhan yang ditujukan oleh besar kecilnya tingkat keuntungan yang diperoleh dalam hubungannya dengan penjualan maupun investasi."

Hery (2015:227) menyatakan "Profitabilitas merupakan rasio yang menggambarkan kemampuan perusahaan dalam menghasilkan laba melalui semua kemampuan dan sumber daya yang dimilikinya, yaitu yang berasal dari kegiatan penjualan, penggunaan aset, maupun penggunaan modal. 'Berdasarkan definisi-definisi tersebut, maka dapat disimpulkan rasio profitabilitas adalah kemampuan perusahaan dalam memperoleh laba dalam satu periode, dengan memanfaatkan aset perusahaan.

Dalam penelitian ini hanya menggunakan satu rasio saja yaitu ROA (Return On Asset). ROA adalah suatu rasio yang digunakan untuk mengukur tingkat pengembalian dari operasional perusahaan dengan menggunakan pemanfaatan sumber daya assetnya. Semakin tinggi nilai rasio ini menunjukkan semakin bagus kemampuan perusahaan dalam mendayagunakan aset yang dimiliki perusahaan untuk memperoleh laba dalam satu periode tertentu. Return on Asset dirumuskan sebagai berikut :

\section{ROA= Laba operasi / total aset X 100}

\subsection{Reputasi Auditor}

Agoes (2012:44), mendefinisikan Kantor Akuntan Publik adalah sebagai berikut : "Suatu bentuk organisasi akuntan publik yang memperoleh izin sesuai dengan peraturan perundang-undangan yang berusaha di bidang pemberian jasa profesional dalam praktik akuntan publik." Pada umumnya Kantor Akuntan Publik (KAP) yang besar mempunyai insentif yang kuat untuk menyelesaikan tugas audit lebih cepat demi mempertahankan reputasinya. Selain itu, KAP besar memiliki lebih banyak sumber daya sehingga tugas audit dapat diselesaikan dalam waktu lebih singkat. KAP besar juga memiliki lebih banyak pengalaman yang membuat mereka dapat melakukan tugas audit lebih cepat. KAP ini dapat menjalankan pengauditan secara lebih efektif dan efisien, serta memiliki fleksibilitas yang lebih tinggi dalam penjadwalan audit.

Berdasarkan Top 100 Firm Accounting Today tahun 2013, KAP terbaik dan terbesar di Indonesia yaitu

1. Deloitte - KAP Osman Bing Satrio

2. PwC (Pricewaterhouse Coopers) - KAP Haryanto Sahari

3. Ernst \& Young - KAP Purwantono, Sarwoko, Sandjaja

4. KPMG - KAP Sidharta, Sidharta, Widjaja

\subsection{Ukuran Perusahaan}

Ukuran perusahaan merupakan nilai yang menunjukan besar kecilnya perusahaan. Ukuran perusahan menunjukan besarnya sekala perusahaan. Ukuran perusahaan dapat diukur oleh total aktiva (asset) perusahaan (Machfoedz:1994 dalam Widaryanti, 2009). Aktiva menurut Keiso (2011:192) adalah sebagai berikut, "asset is aresource controlled by the as a result of past event and from which future economic benefit are expected to flow to the enity". Pernyataan tersebut menjelaskan bahwa aktiva adalah 
sumberdaya dikendalikan oleh suatu perusahaan sebagai akibat peristiwa masa lalu dan diharapkan akan mendapat manfaat ekonomi masa depan untuk perusahaan.Menurut Bambang Riyanto (2018:313) pengertian ukuran perusahaan sebagai berikut:"Besar kecilnya perusaaan dilihat dari besarnya nilai equity, nilai penjualan atau nilai aktiva"Selanjutnya ukuran perusahaan menurut Agus Sartono (2010:249) didefinisakan sebagai berikut "Ukuran perusahaan adalah suatu skala dapat diklasifikasikan besar kecilnya menurut berbagai cara (total aktiva, log size, nilai pasar saham, dan lain-lain). Pada dasarnya ukuran perusahaan hanya terbagi dalam 3 katagori yaitu perusahaan besar (large firm), perusahaan menengah (medium-size) dan perusahaan kecil (small firm). Penentuan ukuran perusahaan ini didasarkan kepada total asset perusahaan" Penelitian ukuran perusahaandapat menggunakan tolak ukur aset. Karna total aset perusahaan bernilai besar maka hal ini dapat disederhanakan dengan mentransformasikan kedalam logaritma natural (Ghozali, 2006) sehingga ukuran perusahaan dapat dihitung dengan

\section{Size $=$ Ln Total Asset}

\section{METODE PENELITIAN}

\subsection{Waktu dan Tempat}

Objek pengamatan dalam penelitian ini mengenai tingkat profitabilitas, reputasi auditordan ukuran perusahaan terhadap audit delay. Perusahaan yang dijadikan objek dalam penelitian ini adalah Perusahaan LQ 45 yang terdaftar di BEI tahun 2010,2011,2012,2013,2014,2015 dan 2016. Data diambil dari Pojok BEJ Universitas Swadaya Gunung Jati.

\subsection{Populasi dan Sampel}

3.2.1 Populasi Peneliti

Populasi pada penelitian ini adalah seluruh perusahaan LQ 45 yang terdpat pada bursa efek indonesi (BEI) dari tahun 2010 sampai dengan tahun 2016.

\subsubsection{Sampel Peneliti}

Pemilihan sampel dilakukan dengan metode purposive sampling dengan melakukan penetapan melalui beberapa kriteria sample. Kriteria tersebut adalah sebagai berikut:

1. Perusahaan yang termasuk dalam kategori LQ 45 .

2. Perusahaan yang menerbitkan laporan keuangan secara periodik dari 2010 sampai dengan 2016.

3. Perusahaan yang menerbitkan laporan keuanganya menggunakan mata uang rupiah.

\subsection{Jenis Penelitian}

Metode penelitian yang di gunakan dalam penelitian ini adalah metode deskriptif asosiatif dengan pendekatan kuantitatif yang bertujuan untuk mengetahui pengaruh dari satu variabel terhadap variabel lainnya yang dalam hal ini adalah melihat pengaruh tingkat profitabilitas, reputasi auditor dan ukuran perusahaan terhadap audit delay di indonesia pada perusahaan LQ-45. Menurut Sugiyono (2012:11), metode deskriptif adalah : "Penelitian yang dilakukan untuk mengetahui nilai variabel mandiri, baik satu variabel atau lebih (independen) tanpa membuat perbandingan, atau menghubungkan antara variabel satu dengan variabel lain.”Menurut Sugiyono (2012:11), metode asosiatif adalah :"Penelitian yang bertujuan untuk mengetahui hubungan antara dua variabel atau lebih."Menurut Sugiyono, (2012:14), pendekatan kuantitatif adalah:Penelitian kuantitatif, adalah penelitian dengan memperoleh data yang berbentuk angka atau data kualitatif yang diangkakan.”

3.3.1Operasionalisasi Variabel

Definisi operasional diperlukan agar konsep yang digunakan dapat di ukur secara tepat, serta menghindari terjadinya kesalahan penafsiran yang berbeda. Definisi operasional dari variabel yang digunakan dalam penelitian ini adalah : 


\subsubsection{Variabel Independent $(\mathrm{X})$}

Menurut Uma Sekaran (2014:117), variabel independent adalah variabel yang mempengaruhi variabel terikat, entah secara positif atau negatif. Pada penelitian ini yang menjadi variable independen atau $\mathrm{X}$ adalah :

1. Tingkat profitabilitas (X1), adalah tingkat kemampuan perusahaan menghasilkan keuntungan (profitabilitas) pada tingkat penjualan, aset dan modal saham tertentu.

2. Reputasi auditor (X2), untuk meningkatkan kredibilitas dari suatu laporan keuangan, perusahaan cenderung menggunakan jasa KAP yang mempunyai reputasi atau nama baik.

3. Ukuran Perusahaan (X3), skala perusahaan yang dilihat dari total aktiva perusahaan pada akhir tahun.

\subsubsection{Variabel Dependent $(\mathbf{Y})$}

Menurut Uma Sekaran (2014:116), variabel dependent merupakan variabel yang menjadi perhatian utama peneliti. Yang menjadi variabel dependent atau fokus utama dari peneliti adalah audit delay. Audit delay merupakan lamanya atau rentang waktu penyelesaian audit yang diukur dari tanggal penutupan tahun buku sampai dengan tanggal diterbitkannya laporan audit Halim (2000)Audit delay merupakan lamanya atau rentang waktu penyelesaian audit yang diukur dari tanggal penutupan tahun buku sampai dengan tanggal diterbitkannya laporan audit.

\subsection{Pemilihan sampel dan pengolahan data}

Objek yang digunakan dalam penelitian ini adalah seluruh perusahaan LQ 45 yang terdaftar di Bursa Efek Indonesia dari tahun 2010 sampai 2016. Sampel dalam penelitian ini dipilih dengan menggunakan metode purposive sampling. Jumlah perusahaan LQ 45 ada 45 perusahaan dan yang memenuhi kriteria ada 24 perusahaan. Data yang digunakan dalam penelitian ini adalah data sekunder yang berbentuk laporan keuangan yang ada di Bursa Efek Indonesia yang diperoleh dari pojok bursa efek indonesia di Universitas Swadaya Gunung Jati. Ada pun Kriteria perusahaan LQ 45 yaitu :

1. Perusahaan yang termasuk dalam kategori LQ 45.

2. Perusahaan yang menerbitkan laporan keuangan secara periodik dari 2010 sampai dengan 2016.

3. Perusahaan yang menerbitkan laporan keuanganya menggunakan mata uang rupiah.

\subsection{Pengukuran Variabel}

\section{Audit delay}

Audit delay diukur secara kuantitatif dalam jumlah hari, yaitu jangka waktu antara tanggal penutupan tahun buku hingga tanggal yang tertera pada laporan auditor independen.

2. Tingkat Profitabilitas

Penelitian ini menggunakan ROA (Return On Asset) yaitu laba bersih dibagi dengan total aset. Perusahaan dengan tingkat profitabilitas tinggi diduga akan menyelesaikan audit lebih cepat dibandingkan perusahaan dengan tingkat profitabilitas rendah.

3. Reputasi Auditor

Variabel ini diukur dengan menggunakan dummy yaitu untuk KAP yang berafiliasi dengan Big Four diberi kode dummy 1, sedangkan KAP yang tidak berafiliasi dengan Big Four diberi kode dummy 0.

4. Ukuran Perusahaan

ukuran perusahaan dapat menggunakan tolak ukur aset. Karna total aset perusahaan bernilai besar maka hal ini dapat disederhanakan dengan mentransformasikan kedalam logaritma natural (Ghozali, 2006) sehingga ukuran perusahaan dapat dihitung sebagai berikut:

\section{Size $=$ Ln Total Asset}

\section{ANALISIS DATA}

\subsection{Statistik Deskritif}

Statistik deskritif memberikan gambaran atau deskritif suatu data yang dilihat dari minimum, maksimum, rata-rata (mean) dan standar devisiasi. Berikut ini adalah hasil statistik deskritif dari variabel yang ditunjukan pada tabel 1 . 
Tabel 1. Hasil Statistik Deskritif Dari Variabel

\begin{tabular}{|l|l|l|l|l|l|}
\hline & & & & & $\begin{array}{l}\text { Std. } \\
\text { Deviatio } \\
\text { n }\end{array}$ \\
\hline AuditDelay & $\mathrm{N}$ & Minimum & Maximum & Mean & 21,0402 \\
Profitabilitas & 168 & 16,00 & 144,00 & 63,0476 & 5 \\
ReputasiAuditor & 168 &,- 01 &, 56 &, 1090 &, 11339 \\
UkuranPerusahaan & 168 & 0,00 & 1,00 &, 7798 &, 41565 \\
Valid N (listwise) & 168 & 2276 & 34,58 & 30,8519 & 2,26232 \\
\hline
\end{tabular}

Statistik deskritif diatas menunjukan jumlahs ampel yang diteliti sebanyak 168 (24x7) (20102016) perusahaan. VariabelAudit Delay (ADY) memiliki nilai terendah (minimum) sebesar16,00 dan nilai tertinggi (maxsimum) 144,00. Nilai rata - rata audit delaya dalah 63,0476 dengan standar deviasi sebesar 21,04025 . Nilai mean yang lebih besar dari standar deviasi menandakan perbedaan lamanya audit delay sebesar 63,0476 menunjukan bahwa rata-rata audit delay untuk perusahaan yang diteliti adalah 63 $(63,04761905)$ hari yaitu lamanya waktu penyelesaian audit dari akhir tahun fisikal perusahan sampai tanggal laporan audit dikeluarkan.

\subsection{Variabel tingkat profitabilitas $(\mathrm{ROA})$}

Variabel tingkat profitabilitas (ROA) memiliki nilai terendah (minimum) sebesar-0,01 dan nilai tertinggi (maxsimum) 0,56. Nilai rata - rata (mean) tingkat profitabilitas adalah 0,1090 dengan standar deviasi sebesar 0,1133 . Nilai standar devisiasi yang lebih besar dari mean menandakan tidak ada perbedaan profit antar perusahaan kecil, nilai mean yang positif menunjukan bahwa rata-rata perusahaan yang diteliti mengalami keuntungan, nilai minimum sebesar 0,01 dimiliki oleh perusahaan.

\subsection{Reputasi auditor (RA)}

Reputasi auditor (RA) yang dilihat dari kategori KAP yang digunakan perusahaan yang terdaftar di BEI sepanjang tahun 2010- 2016 mempunyai keterlambatan terendah 0,00 hari dan keterlambatan tertinggi selama 1,00 hari. Rata-rata (mean) keterlambatan dari 24 perusahaan tersebut adalah selama 0,7798 atau kurang dari 1 hari. Penyimpangan dari nilai rata-rata adalah selama 0,41565 atau kurang dari 1 hari.

\subsection{Variabel ukuran perusahaan}

Variabel ukuran perusahaan memiliki nilai terendah (minimum) sebesar 22,76 dan nilai tertinggi (maxsimum) 34,58. Nilai rata - rata (mean) ukuran perusahaan adalah 30,8519 dengan standar deviasi sebesar 2,26232 .

\subsection{Uji Normalitas}

Uji normalitas bertujuan untuk menguji apakah dalam model regresi, variabel independen dengan variabel dependen keduanya mempunyai hubungan distribusi normal atau tidak. Model regresi yang baik adalah mempunyai distribusi data normal. Dalam penelitian ini normalitas menggunakan one-sample Kolmogrov-smirnov test, bila nilai signifikan semua variabel lebih dari 0,05 maka variabel tersebut telah terdistribusi normal. Berikut ini adalah hasil Uji Normalitas yang ditunjukan tabel 2. 
Tabel 2. One-Sample Kolmogorov-Smirnov Test

\begin{tabular}{|c|c|c|}
\hline & & Unstandardized Residual \\
\hline $\mathrm{N}$ & & 168 \\
\hline \multirow[t]{2}{*}{ Normal Parameters ${ }^{\mathrm{a}, \mathrm{b}}$} & Mean & ,0000000 \\
\hline & Std. Deviation & 17,49896630 \\
\hline \multirow[t]{3}{*}{ Most Extreme Differences } & Absolute & 056 \\
\hline & Positive & 046 \\
\hline & Negative &,- 056 \\
\hline Kolmogorov-Smirnov Z & & ,726 \\
\hline Asymp. Sig. (2-tailed) & & 668 \\
\hline
\end{tabular}

a. Test distribution is Normal.

b. Calculated from data.

Hasil pada tabel 2 diatas menunjukan bahwa hasil uji ormalitas Kolmogorov - Smirnov pada variable tingkat profitabilitas, reputasi auditor, ukuran perusahaan dan audit delay, data sudah distribusikan normal. Hal tersebut ditunjukan dengan nilai Asymp.Sig ( 2-tailed) sebesar 0,668 yang lebih besar dari 0,05. Hal tersebut menunjukan bahwa dalam model regresi, data terdistribusi secara normal sehingga model penelitian dinyatakan telah memenuhi asumsi normalitas.

\subsection{Uji Multikolonearitas}

Uji multikolonearitas bertujuan untuk menguji apakah model regresi di temukan adanya kolerasi antara variabelbebas (independen). Model regresi yang baik seharusnya tidakterjadi kolerasiantara variabel independen. Uji multikolonearitas dapat dilakukan dengan melihat nilai tolerence dan variance inflation factor $(V I F)$. Nilai cuttof yang umum dipakai untuk menunjukan adanya multikolonearitasadalah nila tolerence < 0,10atau sama dengan nilai VIF > 10.(Ghozali,2014). Hasil uji multikolonearitas ditunjukan pada tabel 3 .

Tabel 3. Coefficients ${ }^{\mathrm{a}}$

\begin{tabular}{|c|c|c|c|}
\hline & & \multicolumn{2}{|c|}{ Collinearity Statistics } \\
\hline \multicolumn{2}{|c|}{ Model } & Tolerance & VIF \\
\hline \multirow[t]{4}{*}{1} & (Constant) & & \\
\hline & Profitabilitas & ,812 & 1,232 \\
\hline & ReputasiAuditor & ,834 & 1,199 \\
\hline & UkuranPerusahaan & ,868 & 1,152 \\
\hline
\end{tabular}

a. Dependent Variable: AuditDelay

Berdasarkan tabel bahwa Varian Inflation Factor (VIF) Tingkat Profitabilitas (ROA) adalah 1,232 Reputasi Auditor adalah 1,199 dan Ukuran Perusahaan adalah 1,152 dibawah 10 dan Nilai Tolerance tingkat profitabilitas adalah 0,812 reputasi auditor adalah 0,834 dan ukuran perusahaan 0,868 diatas 0,10 . Hal ini menunjukan bahwa tidak terjadi multikolonearitas dalam metode penelitian, atau tidak ada kolerasi 
yang signifikan antara masing-masing variabel independenya, oleh karena itu pelaksanaan pengujian dapat dilakukan.

\subsection{Uji Heterokedastisitas}

Uji heteroskedastisitas bertujuan untuk menguji apakah dalam model regresi terjadi ketidaksamaan variance dari residual satu pengamatan ke pengamatan yang lain. Model regresi yang baik adalalsh yang homoskedastisitas atau tidak terjadi heteroskedastisitas.Dalam penelitian ini, heteroskedastisitas dideteksi dengan melihat grafik plot. Yang ditunjukan gambar 1.

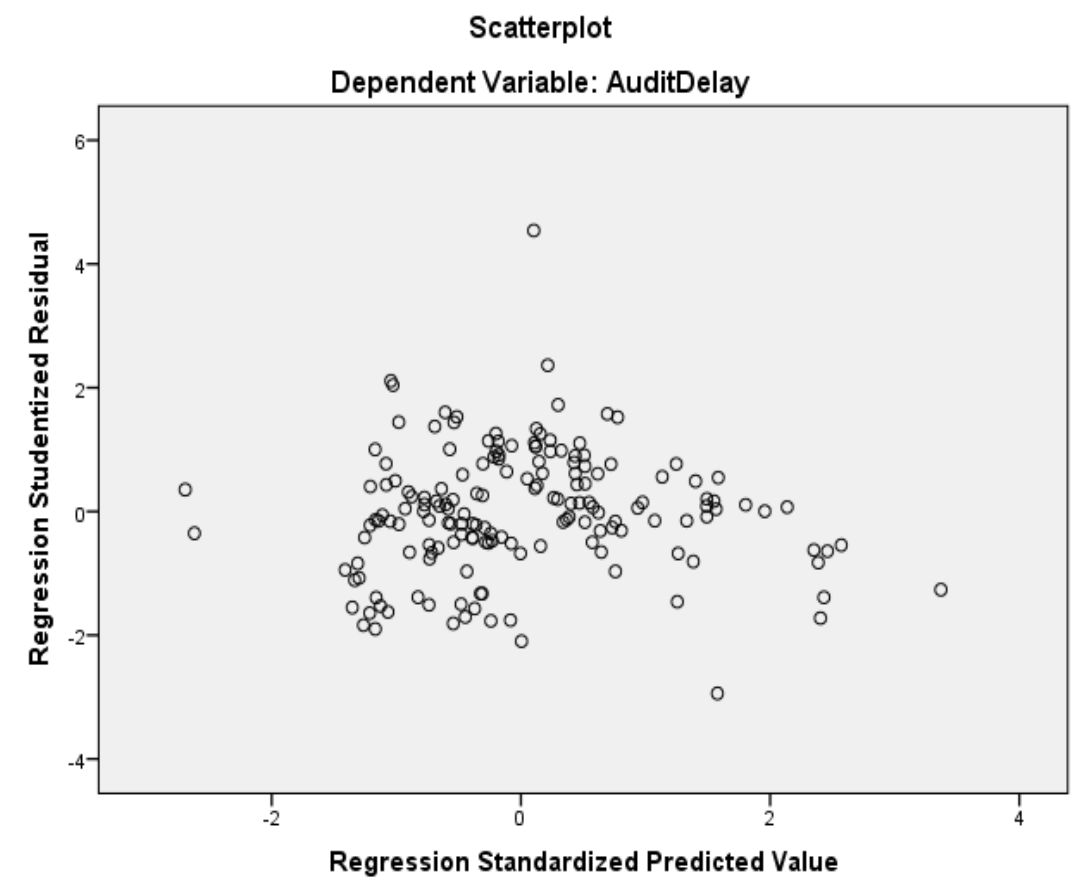

\section{Gambar 1. Scatter Plot}

Berdasarkan gambar diatas menunjukan bahwa titik-titik menyebar secara acak tidak membentuk pola tertentu serta tersebar baik di atasmaupun dibawah angka 0 padasumbu Y. Hal ini dapat disimpulkan bahwa tidak terjadi heteroskedastisitas.

\subsection{Uji Autokolerasi}

Uji autokolerasi bertujuan untuk menguji apakah dalam model regresi linear ada kolerasi antara kesalahan pengganggu pada periode t-1 (sebelumnya). Untuk mengetahui ada tidaknya autokolerasi digunakan metode pengujian DurbinWaston $(d w)$. Model regresi tidakmengandung masalah autokolerasi jika kriteria $d u<d w<4-d u$ ini dipenuhi, ditunukan pada tabel 4. 
Tabel 4. Uji Autokolerasi

\begin{tabular}{|l|l|l|l|l|l|}
\hline & & & & & Std. Error of \\
Model & $\mathrm{R}$ & R Square & Adjusted R Square & $\begin{array}{l}\text { Durbin- } \\
\text { the Estimate }\end{array}$ \\
\hline 1 &, $555^{\mathrm{a}}$ &, 308 &, 287 & 17,76696 & 1,013 \\
\hline
\end{tabular}

a. Predictors: (Constant, Profitabilitas, ReputasiAuditor, UkuranPerusahaan)

b. Dependent Variable: AuditDelay

Tabel diatas menunjukan bahwa nilai Durbin-Waston (dW) sebesar 1,013 terletak diantara nilai batas atas (dU) dengan 4-dU. Hal tersebut menunjukan bahwa dalam model regresi tidak terjadi autokorelasi.

\subsection{Uji Regresi Linier Berganda}

Uji regresi yang digunakan dalam penelitian ini adalah uji regresi berganda. Uji tersebut dilakukan untuk menentukan pengaruh tingkat profitabilitas dan reputasi auditor terhadap audit delay. berikut ini tabel hasil analisis dengan menggunakan SPSS for windows. Uji Regresi Linear Berganda. Ditunjukan pada tabel 5.

Tabel 5. Uji Regresi Linier Berganda

\begin{tabular}{|c|c|c|c|c|c|}
\hline \multirow[b]{2}{*}{ Model } & \multicolumn{2}{|c|}{$\begin{array}{l}\text { Unstandardized } \\
\text { Coefficients }\end{array}$} & \multirow{2}{*}{$\begin{array}{c}\text { Standardized } \\
\text { Coefficients } \\
\text { Beta }\end{array}$} & \multirow[b]{2}{*}{$\mathrm{t}$} & \multirow[b]{2}{*}{ Sig. } \\
\hline & B & Std. Error & & & \\
\hline $1 \quad$ (Constant) & 147,254 & 23,675 & & 6,220 &, 000 \\
\hline Profitabilitas & 41,982 & 13,457 & 226 & 3,120 & ,002 \\
\hline ReputasiAuditor & 6,434 & 3,622 & ,127 & 1,776 & ,078 \\
\hline UkuranPerusahaan & $-3,838$ & ,652 &,- 413 & $-5,884$ & , 000 \\
\hline
\end{tabular}

a. Dependent Variable: AuditDelay

Berdasarkan hasil yang terlihat pada tabel diatas, maka dapat disusun sebuah persamaan regresi linear berganda sebagaiberikut :

\section{$\mathrm{ADY}=147,254+41,982 \mathrm{ROA}+6,434 \mathrm{RA}-3,838 \mathrm{UP}+\mathrm{e}$}

Persamaan Regresi diatas mempunyai makna sebagai berikut:

1. Nilai konstanta regresi adalah positif sebesar 147,254 mempunyai makna bahwa jika nilai profitabilitas, reputasi auditor, ukuran perusahaan dianggap konstan, maka audit delay yang dilakukan oleh perusahan-perusahaan yang diteliti adalah $147(147,254)$ hari.

2. Nilai koefisien regresi untuk variabel tingkat profitabilitas (ROA) sebesar 41,982 dan bertanda positif, artinya apabila ROA mengalami kenaikan 1 satuan, sedangkan independen variabel lain yaitu RA dan UP dianggap konstan, maka audit delay yang dilakukan oleh perusahaan-perusahaan yang diteliti akan bertambah sebesar $42(41,982)$ hari.

3. Nilai koefisien regresi untuk variable reputasi auditor (RA) sebesar 6,434 dan bertanda positif berarti bahwa untuk perusahaan yang menggunakan jasa auditor yang berafiliasi dengan Big four mempunyai waktu audit yang lebih lambat sebesar $6(6,434)$ hari dibandingkan perusahaan yang tidak menggunakan jasa auditor yang berfiliasi Big Four.

4. Nilai koefisien regresi untuk variabel Ukuan Perusahaan sebesar 3,838 dan bertanda negatif, artinya apabila Ukuran Perusahaan mengalami kenaikan 1 satuan, sedangkan independen variabel lain yaitu ROA dan RA, dianggap konstan, maka audit delay yang dilakukan oleh perusahaan-perusahaan yang diteliti akan berkurang sebesar $4(3,838)$ hari. 


\subsection{Pengujian Hipotesis (Uji t)}

Uji statistik pada dasarnya menunjukan seberapa jauh pengaruh satu variabel penjelas atau independen secara individual dalam menerangkan variabel - variabel dependen. Pengambilan keputusan pada uji statistik $t$ dapat dilakukan dengan melihat nilai signifikannya pada taraf kepercayaan 0,05 . Jika nilai signifikannya $>0,05$ maka variabel independen tidak berpengaruh signifikan terhadap variabel dependen, sedangkan jika nilai signifikannya $<0,05$ maka variabel dependen berpengaruh signifikan terhadap variabel dependen. Ditunjukan pada tabel 6 .

Tabel 6. Uji Hipotesis

\begin{tabular}{|c|c|c|c|c|c|c|}
\hline \multirow{2}{*}{\multicolumn{2}{|c|}{ Model }} & \multicolumn{2}{|c|}{ Unstandardized Coefficients } & \multirow{2}{*}{$\begin{array}{c}\begin{array}{c}\text { Standardize } \\
\mathrm{d} \\
\text { Coefficients }\end{array} \\
\text { Beta }\end{array}$} & \multirow[b]{2}{*}{$\mathrm{t}$} & \multirow[b]{2}{*}{ Sig. } \\
\hline & & B & Std. Error & & & \\
\hline \multirow[t]{4}{*}{1} & (Constant) & 147,254 & 23,675 & & 6,220 &, 000 \\
\hline & Profitabilitas & 41,982 & 13,457 & ,226 & 3,120 &, 002 \\
\hline & Reputasi Auditor & 6,434 & 3,622 & ,127 & 1,776 & ,078 \\
\hline & Ukuran Perusahaan & $-3,838$ & ,652 &,- 413 & $-5,884$ &, 000 \\
\hline
\end{tabular}

a. Dependent Variable: AuditDelay

1. Pengaruh Tingkat Profitabilitas (ROA) terhadap Audit Delay

Berdasarkan hasil yang terlihat pada table diatas, maka nilai signifikan untuk ROA $0.02<0,05$ hal ini menunjukan bahwa tingkat profitabilitas (ROA) berpengaruh terhadap audit delay. Dengan demikian maka $\mathrm{H}_{1}$ diterima.

2. Pengaruh Reputasi Auditor (RA) terhadap Audit Delay

Berdasarkan hasil yang terlihat pada table diatas, maka nila isignifikan untuk RA $0.078>0,05$ hal ini menunjukan bahwa reputasi auditor (RA) tidak berpengaruh terhadap audit delay. Dengan demikian maka $\mathrm{H}_{2}$ ditolak.

3. Pengaruh Ukuran Perusahaan (UP) terhadap Audit Delay

Berdasarkan hasil yang terlihat pada table diatas, maka nilaisignifikan untuk UP $0.000<0,05$ hal ini menunjukan bahwa Ukuran Perusahaan (UP)berpengaruh terhadap audit delay. Dengan demikian maka $\mathrm{H}_{3}$ diterima.

\subsection{Koefisien Determinasi}

Koefisien determinasi $\left(\mathrm{R}^{2}\right)$ pada intinya mengukur seberapa jauh kemampuan model dalam menerangkan variasi variabel dependen.Nilai koefisien determminasi adalah antara nol dan satu.Nilai $\mathrm{R}^{2}$ yang kecil berarti kemampuan variavel - variabel dependen dalam menjelaskan variabel - variabel dependen amat terbatas.Nilai yang mendekati satu berarti variabel - variabel independen memberikan hampir semua informasi yang dibutuhkan untuk memprediksi variasi variabel dependen.ditunjkan pada tabel 7. 
Tabel 7. Koefisien Determinasi

\begin{tabular}{|l|r|r|r|r|r|}
\hline & & & & & \\
Model & $\mathrm{R}$ & \multicolumn{1}{|c|}{ R Square } & \multicolumn{1}{c|}{$\begin{array}{c}\text { Adjusted R } \\
\text { Square }\end{array}$} & $\begin{array}{c}\text { Std. Error of } \\
\text { the Estimate }\end{array}$ & $\begin{array}{c}\text { Durbin- } \\
\text { Watson }\end{array}$ \\
\hline 1 &, $555^{\mathrm{a}}$ &, 308 &, 287 & 17,76696 & 1,013 \\
\hline
\end{tabular}

a. Predictors: (Constant), Profitabilitas, ReputasiAuditor, UkuranPerusahaan

b. Dependent Variable: AuditDelay

Berdasarkan tabel diatas dapat dijelaskan dengan melihat angka Adjusted R square atau Koefisien determinasi adalah 0.287. Angka tersebut menunjukan bahwa variasi audit delay (ADY) dapat di jelaskan oleh tingkat profitabilitas (ROA), reputasi auditor (RA), Ukuran Perusahaan, sebesar 28,7\% adapun sisanya $71,3 \%$ dipengaruhi oleh variabel lain.

\section{KESIMPULAN DAN SARAN}

\subsection{Kesimpulan}

Berdasarkan hasil penelitian dan pembahasan maka dapat disimpulkan :.

1. Berdasarkan hasil pengujian menunjukan bahwa tingkat profitabilitas berpengaruh terhadap audit delay.

2. Berdasarkan hasil pengujian menunjukkan bahwa reputasi auditor tidak berpengaruh terhadap audit delay.

3. Berdasarkan hasil pengujian menunjukkan bahwa ukuran perusahaan berpengaruh terhadap audit delay

\subsection{Saran}

Bagi peneliti selanjutnya diharapkan menambah variabel independen selain, tingkat profitabilitas, reputasi auditor dan ukuran perusahaan sebaiknya menggunakan periode waktu yang lebih lama serta perusahaan yang berbeda, agar peneliti selanjutnya dapat menghasilkan hasil yang lebih baik.

\section{DAFTAR PUSTAKA}

[1] Alvin A. Arens, Randal J. Elder, Mark S. Beasley, Auditing dan Jasa Assurance, Edisi 12, Penerbit Erlangga, Jakarta : 2008

[2] Agoes, Sukrisno. 2012 “Auditing Petunjuk Praktis Pemeriksaan Akuntan Oleh Akuntan Publik”, Jilid 1, Edisi Keempat, Salemba Empat, Jakarta.

[3] Destiana, Ari. 2011. ROA, SIZE, Opini audit dan Kualitas Auditor terhadap Audit Delay yang terdaftar dibursa efek tahun 2008-2010. Jurnal Universitas Dian Nusawantoro, Semarang. 